\title{
Karakterisasi Morfologi Ikan Bujuk (Channa lucius) pada Perairan Danau Singkarak Sumatera Barat, Rawa Banjiran Tanjung Jabung Timur Jambi dan Rawa Banjiran Kampar Riau
}

\author{
Azrita $^{\left.1^{*}\right)}$, Hafrijal Syandri' $^{2)}$, Dahelmi $^{3)}$, Syaifullah $^{3)}$, dan Estu Nugroho ${ }^{4)}$ \\ ${ }^{1)}$ Fakultas Keguruan dan Ilmu Pendidikan, Program Studi Pendidikan Biologi, Universitas Bung Hatta, Padang 25133 \\ ${ }^{2)}$ Fakultas Perikanan dan Ilmu Kelautan, Universitas Bung Hatta, Padang 25133 \\ ${ }^{3}$ Fakultas Matematika dan Ilmu Pengetahuan Alam, Universitas Andalas, Padang 25163 \\ ${ }^{4)}$ Balai Riset Perikanan Budidaya Air Tawar, Bogor 40266
}

Diterima 15-12-2011～Disetujui 29-05-2013

\begin{abstract}
Overfishing, the use of unfriendly-environmental fishing gears, changes of environmental water conditions and diversity of habitats are threaten the continuity of Bujuk fish (Channa lucius) and generate the morphologycal diversity. Consequently, appropriate conservation efforts are needed to preserve the fish. The first phase of these efforts were done through morphological approach. The research was held in 2010 in Singkarak Lake West Sumatera Province, in floodplain, Pematang sub-district Lindung Mendahara Ulu Regency East Tanjung Jabung, Province of Jambi, and in floodplain Mentulik Regency Kampar Kiri Hilir Riau Province. The aims of the research were to analyze the morphological characteristic of the fish with Principal Component Analysis (PCA) and to determine the range of similarity between populations of the fish. Determination of the location of fish sampling was conducted by proposive sampling in which there were 30 samples for every research location. The measurement of the specimen was done by digital calipers on the left of the body, at 4 meristic characters and 19 morphometric characters. The data obtained were analyzed by One Way ANOVA and principal component analysis using Statistical software version 13. The results showed that based on the analysis of morphological characteristics of bujuk fish, populations that exist in Lake Singkarak were different from those of Pematang Lindung floodplain subdistrict Mendahara Ulu Regency East Tanjung Jabung Jambi Province and Mentulik Regency floodplain Kampar Kiri Hilir Province Riau. The meristic difference was on the number of scales along the lateral line with a value of 0.783 . While the main difference on morphometric characters were the snout length with a value of 0.848 , and length of upper jaw with a value of 0.847 . Thus, the study showed that the fish was isolated geographically into two groups, which were Jambi-Riau population and Singkarak Lake population.
\end{abstract}

Keywords: Channa lucius, floodplain, lake, meristic, morfometric

\begin{abstract}
ABSTRAK
Aktivitas penangkapan yang berlebihan, penggunaaan alat tangkap yang tidak ramah lingkungan, perubahan kondisi lingkungan perairan, dan adanya perbedaan habitat menyebabkan kelestarian ikan bujuk (Channa lucius) menjadi terancam dan terdapatnya perbedaan morfologi. Untuk itu, diperlukan upaya konservasi yang tepat untuk melestarikan ikan ini. Tahap awal adalah melalui pendekatan morfologi. Penelitian dilakukan pada tahun 2010 di perairan Danau Singkarak, rawa banjiran Kabupaten Tanjung Jabung Timur Jambi dan rawa banjiran Mentulik Regency Kabupaten Kampar Riau. Tujuannya adalah untuk menganalisis karakter morfologi sebagai pembeda utama dan mendeterminasi jarak kemiripan antar populasi ikan bujuk. Penentuan lokasi pengambilan contoh ikan dilakukan secara purposive sampling sebanyak 30 ekor untuk setiap lokasi penelitian. Pengukuran spesimen dengan kaliper digital pada sisi tubuh sebelah kiri, dengan 4 karakter meristik dan 19 karakter morfometrik. Data yang diperoleh dianalisis dengan One Way ANOVA sedangkan analisis komponen utama dan analisis diskriminan menggunakan Software Statistica versi 13. Hasil penelitian menunjukkan bahwa terdapat perbedaan karakter morfologi ikan bujuk antar habitat perairan, pembeda utama dari karakter meristik adalah jumlah sisik sepanjang gurat sisi dengan nilai 0,783. Sedangkan pembeda utama dari karakter morfometrik adalah panjang moncong dengan nilai
\end{abstract}

\footnotetext{
*Telp: +628126734212

Email: azrita31@yahoo.com
} 
0,848 dan panjang rahang atas dengan nilai 0,847 . Berdasarkan pada analisis diskriminan populasi ikan bujuk terisolasi secara geografis menjadi dua kelompok yaitu kelompok populasi Jambi dengan Riau dan kelompok populasi Danau Singkarak.

Kata Kunci: Channa lucius, danau, rawa banjiran, meristik, morfometrik

\section{PENDAHULUAN}

Identifikasi populasi ikan saat ini telah menjadi suatu bagian terpenting dalam upaya manajemen sumber daya perikanan perairan umum daratan yang sudah terancam punah (Beacham et al. 1985a; Beacham et al. 1985b; Wibowo et al. 2008). Identifikasi populasi telah digunakan untuk berbagai tujuan antara lain memastikan struktur populasi dalam rangka konservasi secara in situ dan ex situ (Sunarno et al. 2007). Karakteristik populasi ikan dapat dilakukan melalui pengukuran morfologi (meristik dan morfometrik) sebagai bentuk interaksinya dengan lingkungan (Gustiano 2003), karena faktor lingkungan dapat mempengaruhi struktur morfologi dan genetik ikan (Turan et al. 2004). Ikan putak (Notopterus notopterus) yang hidup di Sungai Ogan, Kelekar, Bangka, Kota Bangun dan Tanah Ulu merupakan populasi yang terpisah akibat isolasi geografis (Wibowo et al. 2009). Isolasi secara geografis juga terjadi pada ikan belida (Chitala lopis) yang hidup di perairan Sungai Kampar Provinsi Riau, Sungai Tulang Bawang Provinsi Lampung dan Sungai Kapuas Provinsi Kalimantan Barat (Sunarno et al. 2007).

Salah satu komoditas penting yang menjadi unggulan untuk diketahui karakter morfologinya adalah ikan bujuk (Chana lucius) famili Channidae yang lebih populer dengan nama snakehead (Kottelat et al. 1993; Samuel et al. 2002; Muflikhah 2007; Syandri et al. 2009). Ikan bujuk sudah jarang ditemukan di rawa banjiran Sungai Batanghari dan Danau Arang-Arang Jambi (Samuel et al. 2002), di Danau Singkarak (Syandri et al. 2009), dan di perairan rawa banjiran Sungai Mandau Riau (Alawi et al. 2008). Di perairan rawa banjiran Sungai Musi Kabupaten Muara Enim dan Kabupaten Musi Banyuasin pada tahun 2004 produksi ikan bujuk sebanyak $2.989 \mathrm{~kg}$, lebih sedikit daripada ikan gabus sebanyak $18.446 \mathrm{~kg}$ dan ikan toman sebanyak $64.797 \mathrm{~kg}$ (Said 2007).

Menurunnya populasi ikan bujuk pada beberapa habitat hidupnya dikarenakan ikan ini mempunyai nilai ekonomis penting dan digemari oleh masyarakat karena rasa dagingnya lezat dan tebal (Gafar \& Nasution 1990; Said 2007), selain itu, ikan bujuk berpotensi untuk dijadikan ikan hias (Syandri et al. 2009). Ikan bujuk dapat dikategorikan ke dalam kriteria rawan (vulnerable), yaitu jenis ikan yang tidak segera terancam punah tetapi terdapat dalam jumlah sedikit dan eksploitasinya terus berjalan.
Penelitian ini bertujuan untuk mengindentifikasi karakteristik meristik dan morfometrik ikan bujuk di Danau Singkarak Provinsi Sumatera Barat, rawa banjiran Kabupaten Tanjung Jabung Timur Provinsi Jambi dan rawa banjiran Kabupaten Kampar Provinsi Riau. Diharapkan informasi ini menjadi masukan yang berharga sebagai suatu dasar untuk manajemen populasi ikan bujuk dalam program konservasi dan domestikasi ikan bujuk di masa yang akan datang.

\section{BAHAN DAN METODE}

Waktu dan Tempat Penelitian. Penelitian dimulai bulan Januari hingga November 2010, dilakukan di kawasan: 1). Perairan Danau Singkarak Kecamatan X Koto Singkarak Kabupaten Solok Provinsi Sumatera Barat terletak pada 100²6’15"-101'31'46" BT dan 00³1'46"-0042’20"LS, elevasi 360-363 m dpl; 2). Rawa banjiran Desa Pematang Lindung Kecamatan Mandahara Ulu Kabupaten Tanjung Jabung Timur Provinsi Jambi terletak 108²4'20"-108²5'20" BT dan 00¹6'60"-00²7’21" LS, elevasi 10-12 m dpl; 3). Rawa banjiran Desa Mentulik Kecamatan Kampar Kiri Hilir Kabupaten Kampar Provinsi Riau terletak pada 101'23'64"-101'24'13" BT dan 00¹1'13"-0009'32" LS, elevasi 12-15 m dpl. Posisi lokasi penelitian tersebut ditentukan dengan alat Garmin GPSMAP tipe 60CSx sensors and maps (Gambar 1).

Karakter Morfologi. Pengukuran karakter morfologi yang dilakukan adalah meristik dan morfometrik. Meristik adalah bagian yang dapat dihitung dari ikan yang merupakan jumlah bagian-bagian tubuh ikan, misalnya jumlah duri pada sirip perut. Morfometrik adalah perbandingan ukuran relatif bagian-bagian tubuh ikan. Perbedaan morfologis antar populasi dapat berupa perbedaan seluruh ukuran dan bentuk, tetapi pada umumnya melibatkan keduanya (Sprent 1972). Perbedaan bentuk antar populasi ikan dinyatakan sebagai fungsi ukuran (McGlade \& Boulding 1985).

Pengukuran morfometrik spesimen dilakukan dengan menggunakan digital kaliper yang memiliki ketelitian 0,10 mm, sedangkan meristik dilakukan penghitungan manual dibantu kaca pembesar. Metode pengukuran dengan menggunakan manual digital kaliper adalah metode yang sampai saat sekarang paling banyak digunakan dalam studi morfologi, paling tidak terdapat 31 dari 42 studi tentang subjek ini yang telah dipublikasikan, termasuk untuk mengukur morfometrik 


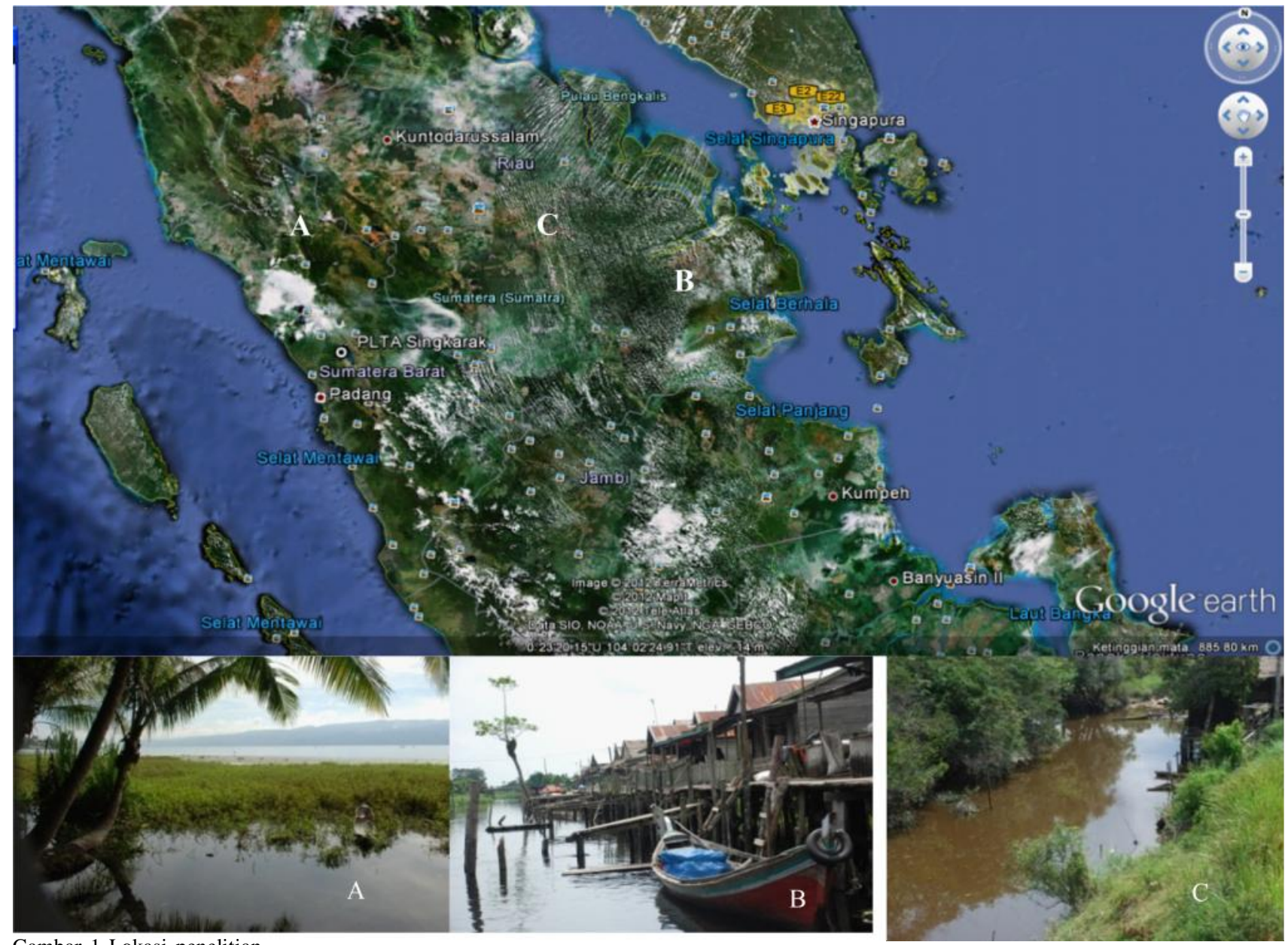

Gambar 1 Lokasi penelitian

Keterangan: A. Danau Singkarak, B. Rawa banjiran Desa Pematang Lindung Jambi, C. Rawa banjiran Desa Mentulik Kampar Kiri Riau

ikan belida (Wibowo et al. 2008). Pengukuran karakter meristik dan morfometrik ikan bujuk dilakukan pada 23 karakter morfologi bentuk badan pada bagian sisi kiri tubuh ikan. Karakter morfometrik diwakili oleh data yang tidak terpisahkan atau continuos data. Meristik diwakili oleh data yang terpisah atau non continuos data (Wibowo et al. 2009). Metode yang digunakan untuk menggambarkan perbedaan bentuk tubuh ikan bujuk mengacu kepada Strauss \& Bookstein (1982) meliputi pengukuran jarak titik-titik tanda yang dibuat pada kerangka tubuh (Gambar 2) .

Analisis Data Karakter Morfologi. Untuk mengetahui perbedaan karakter merisitik dan morfometrik ikan bujuk antara lokasi penelitian digunakan uji One Way ANOVA, selanjutnya untuk mengetahui faktor pembeda utama dari karakter morfologi digunakan analisis komponen utama PCA (Principle Component Analysis). PCA merupakan salah satu metode yang paling sering digunakan untuk permasalahan biologi dan sejauh ini merupakan metode yang paling luas digunakan untuk analisis morfometrik, sedangkan untuk pengelompokan populasi ikan bujuk digunakan analisis diskriminan. Data dianalisis dengan menggunakan program SPSS versi 13.0 .

\section{HASIL DAN PEMBAHASAN}

Karakter Meristik dan Morfometrik. Data rataan karakteristik meristik dan morfometrik ikan bujuk yang berasal dari Danau Singkarak Sumatera Barat, rawa banjiran Tanjung Jabung Timur Jambi dan rawa banjiran Kampar Riau disajikan pada Tabel 1.

Dari Tabel 1 dapat dikemukan bahwa berdasarkan analisis One Way ANOVA, dari empat karakter meristik terdapat satu karakter sisik di atas gurat sisi (b) yang tidak berbeda nyata $(p>0,05)$ antara populasi ikan bujuk Danau Singkarak Sumatera Barat, rawa banjiran Tanjung Jabung Timur Jambi dan rawa banjiran Kampar Riau. Selanjutnya dari 19 karakter morfometrik terdapat tiga karakter yang tidak berbeda ( $p>0,05)$ yaitu tinggi batang ekor (3), panjang batang ekor (4) dan panjang moncong (15). Perbedaan karakter meristik dan morfometrik pada ikan bujuk disebabkan oleh perbedaan habitat tempat hidup ikan tersebut, terutama 


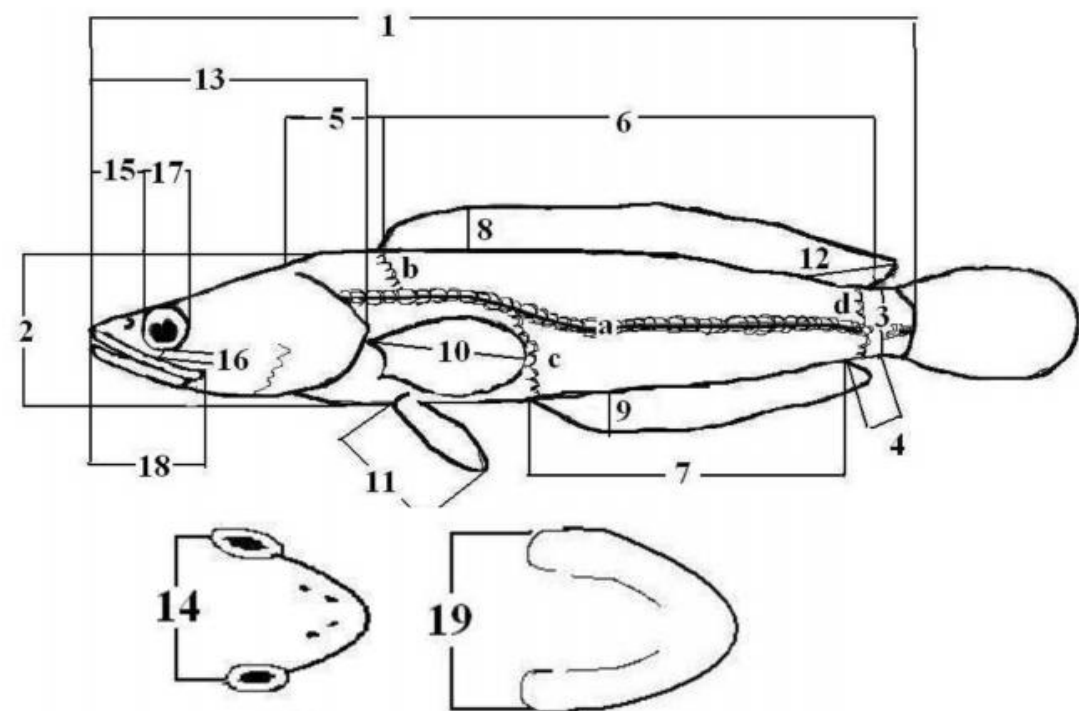

Gambar 2 Skema pengukuran morfologi ikan bujuk, a). Sisik sepanjang gurat sisi; b). Sisik di atas gurat sisi; c). Sisik di bawah gurat sisi; d). Sisik di sekeliling batang ekor; 1). Panjang standar; 2). Tinggi tubuh; 3). Tinggi batang ekor; 4). Panjang batang ekor; 5). Panjang nape; 6). Panjang dasar sirip dorsal; 7). Panjang dasar sirip anal; 8). Tinggi sirip dorsal; 9). Tinggi sirip anal; 10). Panjang sirip pektoral; 11). Panjang sirip pelvik; 12). Panjang duri sirip dorsal yang terpanjang; 13). Panjang kepala; 14). Lebar kepala; 15). Panjang moncong; 16). Lebar suborbital; 17). Diameter mata; 18). Panjang rahang atas; 19. Lebar 'gape'

Tabel 1 Data karakteristik meristik dan morfometrik ikan bujuk

\begin{tabular}{|c|c|c|c|}
\hline Ciri fenotipik & Sumatera Barat & Jambi & Riau \\
\hline \multicolumn{4}{|c|}{ Karakter Meristik (unit) } \\
\hline sisik sepanjang gurat sisi (a) & $57,00 \pm 0,89^{\mathbf{a}}$ & $59,00 \pm 2,04^{\mathbf{b}}$ & $61,00 \pm 3,18^{\mathbf{c}}$ \\
\hline sisik di atas gurat sisi (b) & $6,00 \pm 0,43^{\mathbf{a}}$ & $6,00 \pm 0,34^{\mathbf{a}}$ & $7,00 \pm 0,34^{\mathbf{a}}$ \\
\hline sisik di bawah gurat sisi (c) & $11,00 \pm 1,32^{\mathrm{a}}$ & $11,00 \pm 0,58^{\mathrm{b}}$ & $12,00 \pm 2,38^{\mathrm{c}}$ \\
\hline sisik di sekeliling batang ekor (d) & $\begin{array}{c}18,00 \pm 1,28^{\mathrm{a}} \\
\text { Karakter Mo }\end{array}$ & $18,00 \pm 1,22^{\mathrm{a}}$ & $19,00 \pm 1,04^{\mathrm{c}}$ \\
\hline panjang standar (1) & $20,76 \pm 0,84^{\mathrm{a}}$ & $22,04 \pm 1,20^{\mathrm{b}}$ & $24,82 \pm 1,84^{\mathrm{c}}$ \\
\hline tinggi tubuh (2) & $3,45 \pm 0,69^{\mathrm{a}}$ & $3,92 \pm 0,38^{\mathrm{b}}$ & $4,08 \pm 0,50^{\mathrm{b}}$ \\
\hline tinggi batang ekor (3) & $2,45 \pm 0,55^{\mathrm{a}}$ & $2,44 \pm 0,54^{\mathrm{a}}$ & $2,24 \pm 0,28^{a}$ \\
\hline panjang batang ekor (4) & $1,38 \pm 0,36^{\mathrm{a}}$ & $1,37 \pm 0,40^{\mathrm{a}}$ & $1,41 \pm 0,36^{\mathrm{a}}$ \\
\hline panjang nape (5) & $2,26 \pm 0,56^{\mathrm{a}}$ & $2,39 \pm 0,63^{\mathrm{a}}$ & $2,81 \pm 0,90^{\mathrm{b}}$ \\
\hline panjang dasar sirip dorsal (6) & $12,36 \pm 1,36^{\mathrm{a}}$ & $13,61 \pm 1,46^{\mathrm{b}}$ & $15,43 \pm 1,76^{\mathrm{c}}$ \\
\hline panjang dasar sirip anal (7) & $9,47 \pm 0,96^{\mathrm{a}}$ & $10,15 \pm 0,98^{\mathrm{b}}$ & $10,93 \pm 1,43^{\mathrm{c}}$ \\
\hline tinggi sirip dorsal (8) & $1,27 \pm 0,06^{\mathrm{a}}$ & $1,30 \pm 0,10^{\mathrm{b}}$ & $1,42 \pm 0,17^{\mathrm{c}}$ \\
\hline tinggi sirip anal (9) & $1,21 \pm 0,10^{\mathrm{a}}$ & $1,25 \pm 0,14^{\mathrm{b}}$ & $1,38 \pm 0,22^{\mathrm{c}}$ \\
\hline panjang sirip pectoral (10) & $3,36 \pm 0,26^{\mathrm{a}}$ & $3,40 \pm 0,29^{\mathrm{a}}$ & $2,83 \pm 0,34^{b}$ \\
\hline panjang sirip pelvic (11) & $2,65 \pm 0,26^{\mathrm{a}}$ & $2,74 \pm 0,32^{b}$ & $2,96 \pm 0,31^{\mathrm{c}}$ \\
\hline panjang duri sirip dorsal yg terpanjang (12) & $2,28 \pm 0,23^{\mathrm{a}}$ & $2,40 \pm 0,40^{\mathrm{a}}$ & $2,75 \pm 0,49^{\mathrm{b}}$ \\
\hline panjang kepala (13) & $6,48 \pm 0,52^{\mathrm{a}}$ & $6,58 \pm 0,55^{\mathrm{b}}$ & $7,17 \pm 0,80^{\mathrm{c}}$ \\
\hline lebar kepala (14) & $2,44 \pm 0,43^{\mathrm{a}}$ & $2,60 \pm 0,45^{\mathrm{a}}$ & $3,09 \pm 0,48^{b}$ \\
\hline panjang moncong (15) & $1,89 \pm 0,69^{\mathrm{a}}$ & $1,58 \pm 0,62^{\mathrm{a}}$ & $1,29 \pm 0,57^{\mathrm{a}}$ \\
\hline lebar suborbital (16) & $0,11 \pm 0,03^{\mathrm{a}}$ & $0,11 \pm 0,03^{\mathrm{a}}$ & $0,17 \pm 0,20^{\mathrm{b}}$ \\
\hline diameter mata (17) & $0,63 \pm 0,07^{\mathrm{a}}$ & $0,66 \pm 0,08^{\mathrm{a}}$ & $0,75 \pm 0,10^{\mathrm{b}}$ \\
\hline panjang rahang atas (18) & $2,19 \pm 0,21^{\mathrm{a}}$ & $2,30 \pm 0,25^{\mathrm{a}}$ & $2,87 \pm 0,60^{\mathrm{b}}$ \\
\hline lebar 'gape' (19) & $1,66 \pm 0,15^{\mathrm{a}}$ & $1,74 \pm 0,17^{\mathrm{a}}$ & $2,10 \pm 0,28^{b}$ \\
\hline
\end{tabular}

Keterangan: Rataan \pm SD $(n=30)$ dengan huruf superscript yang berbeda menunjukan berbeda nyata ( $<<0,05)$ dan huruf superscript yang sama menunjukan tidak berbeda nyata $(p>0,05)$

berhubungan dengan parameter kualitas air, pembeda utama dari parameter kualitas pada tiga habitat adalah kesadahan air yang berhubungan dengan $\mathrm{pH}$ air. Nilai kesadahan di perairan Danau Singkarak rata-rata 72,00 $\pm 3,00 \mathrm{mg} / \mathrm{L}$ dan $\mathrm{pH}$ rata-rata 7,56 $\pm 0,40$, di rawa banjiran Tanjung Jabung Timur Jambi kesadahan rata-rata 3,06 $\pm 0,11 \mathrm{mg} / \mathrm{L}$ dan $\mathrm{pH}$ rata-rata $4,50 \pm 0,45$, sedangkan di rawa banjiran Kampar Riau kesadahan rata-rata 4,05 $\pm 0,18 \mathrm{mg} / \mathrm{L}$ dan $\mathrm{pH}$ rata-rata 4,40 \pm 0,51. Kesadahan (hardness) menggambarkan kandungan garam-garam alkali tanah yaitu garam-garam yang dapat dititrasi dengan asam kuat (alkalinitas) dan tidak dapat dititrasinya, misalnya garam-garam alkali tanah, seperti $\mathrm{CaCl}_{2}$, $\mathrm{MgSO}_{4}$ dan sebagainya. Di perairan tawar, kation divalen (bervalensi dua) yang berlimpah adalah kalsium, dan magnesium sehingga kesadahan dapat digunakan sebagai petunjuk kandungan garam-garam dari kedua kation alkali tanah tersebut. 
Secara biometrik, terdapat perbedaan ukuran populasi ikan bujuk, dari analisis One Way ANOVA terhadap karakter meristik dan morfometrik memperlihatkan bahwa populasi ikan bujuk yang ada di rawa banjiran Tanjung Jabung Timur Jambi dan rawa banjiran Kampar Riau memiliki ukuran karakteristik hampir sama. Hal ini disebabkan oleh kedekatan geografis yang memungkinkan terjadi aliran gen dan kondisi lingkungan yang relatif sama yaitu rawa banjiran (air hitam bersifat asam). Perbedaan karakter meristik dan morfometrik yang lebih besar terdapat antara populasi Danau Singkarak Sumatera Barat dengan populasi rawa banjiran Kampar Riau. Erat kaitannya dengan isolasi geografis dan pengaruh lingkungan, habitat populasi ini berbeda (air kuning coklat bersifat basa). Pada ikan belida (Chitala spp.) dari hasil analisis morfometrik dan meristik memperlihatkan bahwa populasi yang ada di Riau (waduk PLTA Koto Panjang, Kampar Kiri, Tapung Kanan, dan Kerinci) memiliki jarak genetik yang lebih dekat satu sama lain. Hal ini disebabkan oleh kedekatan geografis yang memungkinkan terjadi aliran gen dan kondisi lingkungan yang relatif sama (Wibowo et al. 2008) Untuk mengetahui karakter utama yang paling menentukan perbedaan ciri meristik dan morfometrik ikan bujuk dari populasi Danau Singkarak Sumatera Barat, rawa banjiran Kabupaten Tanjung Jabung Timur Jambi dan rawa banjiran Kabupaten Kampar Riau dilakukan analisis data dengan menggunakan uji Principal Component Analysis (PCA). Berdasarkan pada Tabel 2, dibuat karakter dominan yang muncul dari tiga populasi ikan bujuk secara berurutan disajikan pada Tabel 3.

Dari Tabel 3 tersebut maka faktor pembeda dari karakter meristik yang paling utama menentukan adalah jumlah sisik di atas gurat sisi, sedangkan dari karakter morfometrik pembeda utama secara berurutan dari tiga populasi ikan bujuk ditentukan oleh empat karakter, yaitu: 1). panjang moncong; 2). panjang rahang atas; 3). panjang sirip pektoral; dan 4) panjang duri sirip dorsal yang terpanjang. Pembeda dari karakter panjang moncong dan panjang rahang atas disebabkan karena ikan bujuk bersifat predator murni yaitu menyergap makanan berupa anak ikan, udang kecil dan anak katak, sehingga memerlukan mulut yang panjang dan rahang lebar untuk memakan makanannya. Pembeda karakter panjang sirip pektoral dan panjang duri sirip dorsal yang terpanjang disebabkan oleh ikan bujuk melakukan pergerakan dari dasar ke permukaan perairan untuk menyergap makanan. Setiap spesies ikan memiliki ciri meristik dan morfometrik sebagai pembeda utama. Sebagai contoh adalah ikan belida (Chitala spp., Siluridae) bersifat karnivora, hidup di perairan umum daratan di Sungai Tulang Bawang Lampung, Kampar Riau dan Kapuas Kalimantan Barat, faktor pembeda utama dari populasi tersebut adalah tinggi pungguk dan lebar mulut (Sunarno et al. 2007). Pada ikan nila (Oreochromis niloticus) karakter yang paling menentukan adalah panjang dasar sirip dorsal (Arifin \& Kurniasih 2007), sedangkan pada ikan putak (Notopterus notopterus) karakter yang paling menentukan

Tabel 2 Nilai koefisien faktor berdasarkan pada kovarian pada PC II dan III

\begin{tabular}{|c|c|c|c|c|c|c|}
\hline \multirow{2}{*}{ Merisik dan morfometrik } & \multicolumn{6}{|c|}{ Komponen } \\
\hline & 1 & 2 & 3 & 4 & 5 & 6 \\
\hline \multicolumn{7}{|c|}{ Karakter Meristik (unit) } \\
\hline sisik sepanjang gurat sisi (a) & ,478 &,- 215 & ,400 &,- 014 &,- 118 & ,466 \\
\hline sisik di sekeliling batang ekor (d) &, 356 &,- 417 &, 567 &,- 106 & ,366 &,- 108 \\
\hline sisik di atas gurat sisi (b) &, 324 & 265 &,- 074 &, 592 & 460 & ,201 \\
\hline sisik di bawah gurat sisi (c) &, 325 &, 164 &, 232 &,- 459 &, 063 & ,330 \\
\hline \multicolumn{7}{|c|}{ Karakter Morfometrik $(\mathrm{cm})$} \\
\hline panjang rahang atas (18) &, 857 &,- 187 &,- 183 & 029 &,- 187 &,- 091 \\
\hline lebar 'gape' (19) &, 855 & ,094 &, 000 &,- 141 &, 125 &,- 070 \\
\hline panjang duri sirip dorsal yg terpanjang (12) &, 823 &,- 209 & ,035 &, 107 &,- 288 &,- 127 \\
\hline panjang sirip pectoral $(10)$ & ,801 &,- 351 &, 122 &,- 107 &, 160 &,- 127 \\
\hline panjang dasar sirip dorsal (6) &, 800 &, 070 & 095 &,- 099 &,- 082 &, 196 \\
\hline panjang standar (1) &, 774 &,- 006 & ,218 &,- 303 &,- 063 &, 131 \\
\hline tinggi sirip anal (9) &, 768 &,- 017 & 074 & ,399 &,- 048 &,- 072 \\
\hline tinggi sirip dorsal (8) & ,766 &,- 102 &,- 055 &, 186 &,- 057 &,- 231 \\
\hline panjang kepala (13) &, 763 &,- 278 &, 007 &, 178 &,- 112 &,- 170 \\
\hline diameter mata (17) &, 758 &, 053 &,- 108 &, 016 &,- 409 &,- 002 \\
\hline panjang sirip pelvic (11) &, 754 & ,272 &,- 002 &, 157 &, 135 &,- 086 \\
\hline lebar kepala (14) &, 738 &, 064 &,- 353 &,- 296 &,- 047 &,- 191 \\
\hline panjang dasar sirip anal (7) &, 722 & ,448 &, 068 &,- 027 &, 174 & 027 \\
\hline tinggi tubuh (2) &, 520 & ,401 & 015 & ,053 & ,208 & , 128 \\
\hline panjang batang ekor (4) &, 075 &,- 614 &, 111 &,- 132 & ,491 &,- 115 \\
\hline panjang nape (5) & ,446 &, 581 &,- 196 &,- 450 &, 128 &, 056 \\
\hline panjang moncong (15) &,- 393 &, 160 &, 711 &,- 094 &,- 374 &,- 120 \\
\hline tinggi batang ekor (3) &, 028 &, 538 &, 542 & ,434 &,- 052 &,- 127 \\
\hline lebar suborbital (16) & ,232 &,- 403 &,- 202 & ,288 &,- 132 & ,649 \\
\hline
\end{tabular}


Tabel 3 Karakter dominan pembeda sifat ikan bujuk

\begin{tabular}{|c|c|}
\hline Faktor pembeda utama secara berurutan & Nilai pembeda di urut dari nilai tertinggi \\
\hline \multicolumn{2}{|l|}{ Meristik } \\
\hline Sisik Diatas Gurat Sisi (b) & 0,783 \\
\hline Sisik Di sekeliling Batang Ekor (d) & 0,778 \\
\hline Sisik Sepanjang Gurat Sisi (a) & 0,666 \\
\hline Sisik dibawah Gurat Sisi (c) & 0,510 \\
\hline \multicolumn{2}{|l|}{ Morfometrik } \\
\hline Panjang Moncong (15) & 0,848 \\
\hline Panjang Rahang Atas (18) & 0,847 \\
\hline Panjang Sirip Pectoral (10) & 0,833 \\
\hline Panjang Duri Sirip Dorsal Terpanjang (12) & 0,832 \\
\hline Lebar Kepala (14) & 0,800 \\
\hline Panjang Nape (5) & 0,797 \\
\hline Tinggi Batang Ekor (3) & 0,791 \\
\hline Lebar Gape (19) & 0,780 \\
\hline Tinggi Sirip Anal (9) & 0,762 \\
\hline Lebar Suborbital (16) & 0,779 \\
\hline Panjang Standar (1) & 0,760 \\
\hline Panjang Dasar Sirip Anal (7) & 0,759 \\
\hline Diameter Mata (17) & 0,757 \\
\hline Panjang Kepala (13) & 0,732 \\
\hline Panjang Dasar Sirip Dorsal (6) & 0,710 \\
\hline Panjang Sirip Pelvic (11) & 0,693 \\
\hline Tinggi Sirip Dorsal (8) & 0,691 \\
\hline Panjang Batang Ekor (4) & 0,667 \\
\hline Tinggi Tubuh (2) & 0,494 \\
\hline
\end{tabular}

adalah panjang moncong (Wibowo et al. 2009). Secara visual dan biometrik perbedaan utama ikan bujuk terlihat pada ukuran panjang total, bentuk, dan warna tubuh (Gambar 2). Hasil tampilan visual ini akan dijelaskan secara kuantitatif dengan analisis diskriminan.

Berdasarkan analisis, diskriminan mengisolasi spesimen ikan bujuk secara alami menjadi dua kelompok yang berbeda (Gambar 3). Ikan bujuk yang berada pada kelompok pertama berada pada sektor positif dan negatif, yaitu populasi yang berasal dari rawa banjiran Tanjung Jabung Timur Jambi dan rawa banjiran Kampar Riau. Kelompok kedua dikelompokkan pada sektor negatif, yaitu populasi yang berasal dari Danau Singkarak Sumatera Barat. Dari hasil penelitian ini dapat dinyatakan bahwa populasi ikan bujuk pada rawa banjiran Tanjung Jabung Timur Jambi dan rawa banjiran Kampar Riau mempunyai hubungan kekerabatan yang lebih dekat (Gambar 4). Meskipun pada Gambar 3 terlihat bahwa populasi ikan bujuk dari Tanjung Jabung Timur Jambi ada sebagian kecil masuk ke dalam kelompok Danau Singkarak Sumatera Barat. Hal ini membuktikan bahwa ikan tersebut termasuk ke dalam satu spesies yaitu $C$. lucius. Selain itu ikan bujuk mempunyai toleransi yang luas terhadap perubahan kualitas air, yaitu dapat hidup pada kisaran kesadahan air 3,06 $\pm 0,11-72,00 \pm$ $3,00 \mathrm{mg} / \mathrm{L}$ dan $\mathrm{pH}$ air berkisar 4,50 $\pm 0,45-7,56 \pm 0,40$. Toleransi yang sangat luas tersebut memberikan peluang untuk konservasi ikan bujuk secara ex situ, terutama untuk melakukan proses domestikasi.
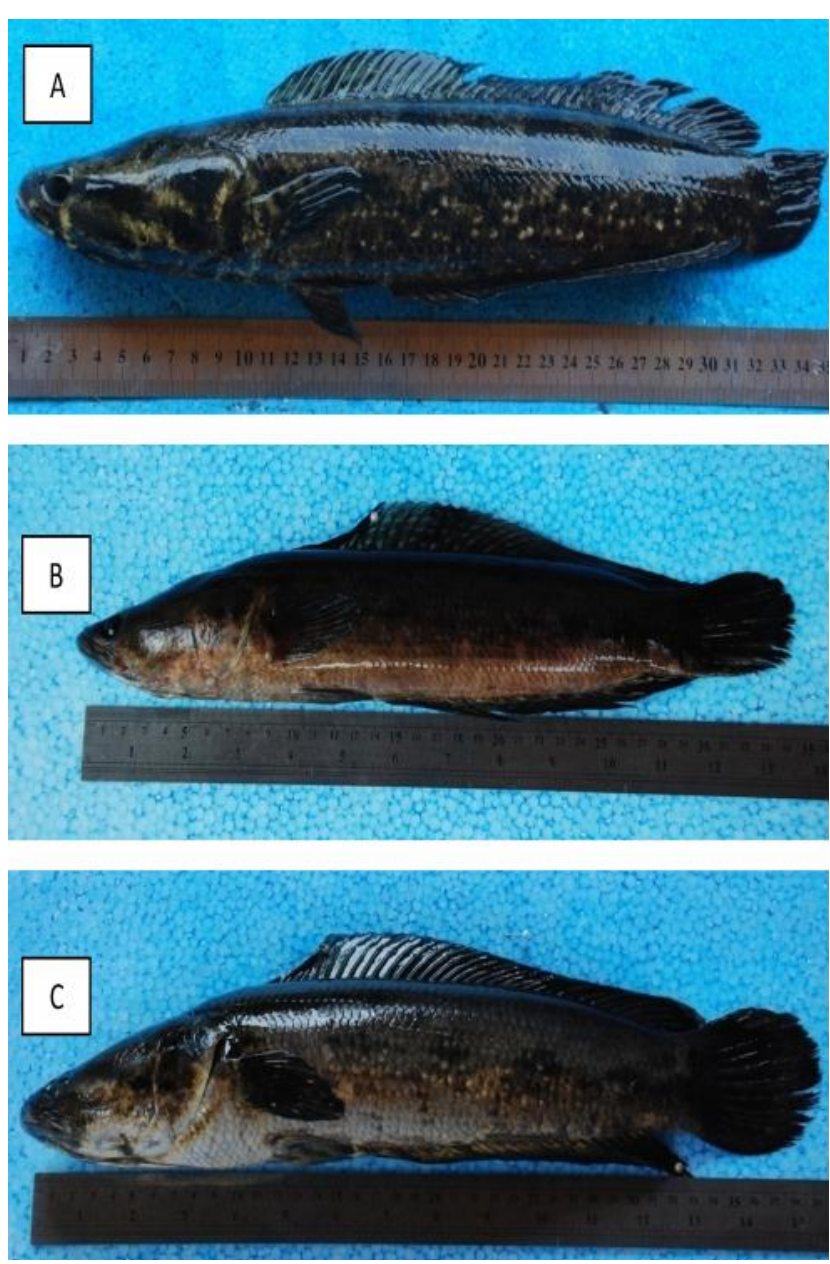

Gambar 2 Ikan bujuk berasal dari A). Danau Singkarak Sumatera Barat; B). Rawa banjiran Desa Pematang Lindung Tanjung Jabung Timur Jambi; C). Rawa banjiran Desa Mentulik Kampar Riau 


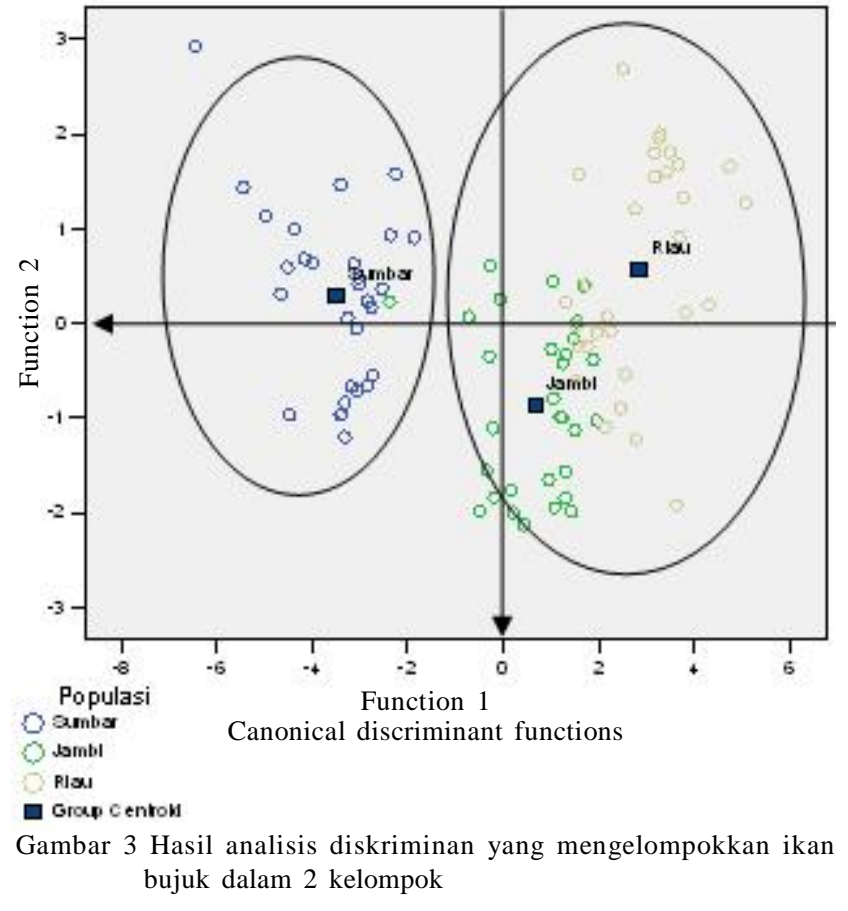

Pengelompokan ini terjadi akibat perbedaan geografis yang berhubungan dengan letak ketinggian habitat dari permukaan laut dan faktor lingkungan, terutama yang berhubungan dengan kualitas air, seperti kesadahan dan $\mathrm{pH}$ air. Perbedaan morfometrik juga ditemukan pada ikan baung yang berasal dari Jambi dengan Wonogiri dan Jatiluhur yang disebabkan oleh adanya halangan secara geografis (Nugroho et al. 2005). Populasi ikan belida (Chitala sp.) yang dahulu merupakan satu populasi, kemudian menjadi populasi yang terpisah dan terisolasi seperti populasi ikan belida pulau Sumatera dan Kalimantan, disebabkan oleh naiknya permukaan air laut akibat mencairnya es pada zaman pleistocen. Populasi yang terisolasi kemudian mengalami perubahan genotipe atau fenotipe, khususnya sifat adaptif yang berkembang melalui seleksi alam, sebagai respon kondisi lingkungan berbeda pada daerah yang secara geografi terpisah (Wibowo et al. 2008). Selanjutnya pengaruh lingkungan, seleksi, dan genetik pada tahap ontogeni individu menyebabkan perbedaan morfometrik di dalam suatu spesies (Turan 2004; Jawad 2001).

\section{SIMPULAN}

Populasi ikan bujuk antar habitat perairan memiliki ukuran yang berbeda. Pembeda utama dari karakter meristik ikan bujuk adalah jumlah sisik di atas gurat sisi, sedangkan dari karakter morfometrik adalah panjang moncong, panjang rahang atas dan panjang sirip pektoral. Populasi ikan bujuk terisolasi menjadi dua kelompok yang berbeda, kelompok

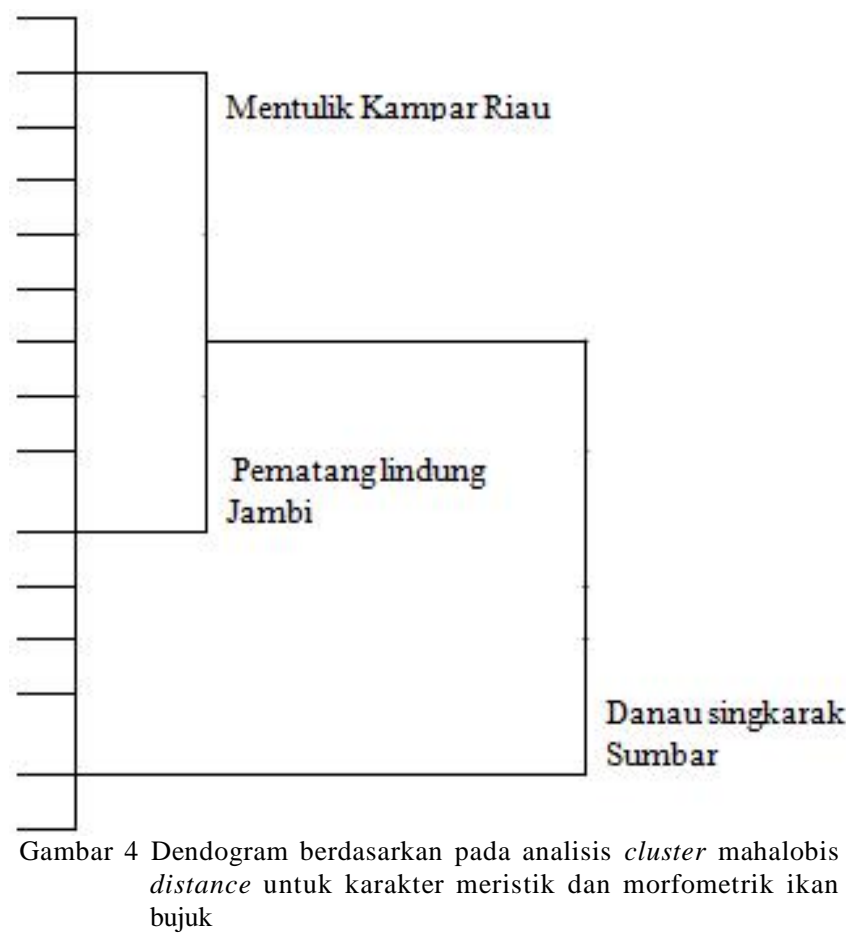

pertama populasi ikan bujuk dari rawa banjiran Tanjung Jabung Timur Jambi dan populasi dari rawa banjiran Kampar Riau, sedangkan populasi Danau Singkarak terpola menjadi satu kelompok tersendiri.

\section{UCAPAN TERIMAKASIH}

Penelitian ini dibiayai oleh Beasiswa Pendidikan pada Pascasarjana Universitas Andalas Padang. Penulis mengucapkan terima kasih kepada Bapak Novirman Jamarun selaku Direktur Program Pascasarjana, Bapak Dahelmi, Hafrijal Syandri, Estu Nugroho, dan Syaifullah sebagai dosen pembimbing yang telah meluangkan waktu untuk memberikan saran dan masukan untuk kesempurnaan artikel ini yang merupakan bagian dari disertasi pada Program Studi Biologi.

\section{DAFTAR PUSTAKA}

Alawi, H., Rengi, P \& Tang, U.M. 2008. Direktori Ikan Komersil Di Perairan Umum Kabupaten Bengkalis, Riau. Pekanbaru: Unri Press.

Amis, M.A., Rouget, M., Lotter, M \& Day, J. 2009. Integrating freshwater and terrestrial priorities in conservation planning. Biol Conserv 142(10): 2217-2226.

Arifin, O.Z \& Kurniasih, T. 2007. Karakteristik morfologi keturunan pertama ikan nila (Oreochromis niloticus) GET dan GIFT berdasarkan metode truss morphometrics. Jurnal Ris Akuakultur 2(3): 377-387.

Azrita, H., Syandri \& Aryani, N. 2010. Studi kadar nutrisi telur ikan Balingka (Puntius blinka) di Danau Singkarak. Makalah disampaikan pada seminar Limnologi IV LIPI di Bogor. 
Beacham, T.D., Withler, R.E \& Gould, A.P. 1985a. Biochemical genetic stock identification of pink salmon (Oncohynchus gorbuscha) in southern Bristish Columbia and Puget Sound. Can J Fish Aqua Sci 42(1): 474-483.

Beacham, T.D., Withler \& Gould, A.P. 1985b. Biochemical genetic stock identification of chum salmon (Oncohynchus keta) in southern Bristish Columbia and Puget Sound. Can J Fish Aqua Sci 42(1): 437-448.

Clayton, R.R \& Mac Crimmon, H.R. 1987. Partitioning size from morphometric data: A comparison of five statistical prosedurs used in fisheries stock indentification research. Can Tehn Rep Fish Aq Serv 1531: 1-23.

Gaffar, A.K \& Nasution, Z. 1990. Upaya domestifikasi ikan perairan umum. Jurnal Litbang Pertanian IX(4): 6975 .

Gustiano, R. 2003. Taxonomy and phylogeny of Pangasiidae Catfishes from Asia (Ostariophysi,Siluriformes). Thesis for the Doctor's Degree (Ph.D). Katholieke Universiteit Leuven. Leuven. Belgium. 296 p.

Gustiano, R., Haryanti \& Sulaeman. 2007. Arah riset biotek breeding perikanan budi daya ke depan. Media Akuakultur 2(1): 164-168.

Jawad, L.A. 2001. Variation in meristic characters of a tilapiaan fish, Tilapia zili (Gervais, 1848) from the inland water bodies in Libya. Acta Ichthyol Piscat 31(1): 159-164.

Kartamihardja, E.S., Purnomo, K \& Umar, C. 2009. Sumber daya perairan umum daratan di Indonesia terabaikan. Jurnal Kebijakan Perikanan Indonesia 1(1): 1-15.

Kottelat, M., Whitten, A.J., with Kartikasari, S.N \& Wirjoatmodjo, S. 1993. Freshwater Fishes of Western Indonesia and Sulawesi. Periplus Edition (HK), Jakarta.

Kristanto, A.H., Asih, S \& Winarlin. 2007. Karakteristik reproduksi dan morfometrik ikan Batak dari dua lokasi (Sumatera Utara dan Jawa Barat). Jurnal Riset Akuakultur 2(1): 59-65.

Mc.Glade, J.M \& Boulding, E. 1985. The truss: A geometric and statistic approach to the analysis of from in fish. Can Tech Rep Fish. Aquacult Sci 147: 34-55.

Muflikhah, N. 2007. Domestikasi ikan gabus (Chana striatus). Jurnal Bawal 1(5): 169-175.

Nei, M. 1987. Moleculer Evolution Genetics. New York: Columbia University Press.

Ng, P.K.L \& Lim, K.K.P. 1990. Snakeheads (Pisces : Channidae) : Natural. History, biology and economic importance : Essays in Zoology, Paper Commemorating the $40^{\text {th }}$.

Nugroho, E, Hadie, W., Subagja, J \& Kurniasih, T. 2005. Keragaman genetik dan morfometrik pada ikan Baung (Mystus nemerus ) dari Jambi, Wonogiri dan Jatiluhur. Jurnal Penelitian Perikanan 11(7 ): 1-6.

Said, A. 2007. Beberapa jenis kelompok ikan Gabus (Marga Chana) di daerah aliran sungan Musi, Sumatera Selatan. Jurnal Bawal 1(4): 121-126.

Samuel., Djie, S.A \& Nasution, Z. 2002. Aspek lingkungan dan biologi ikan di Danau Arang-Arang Provinsi Jambi. JPPI, edisi sumber daya dan penangkapan 1(8): 1-13.
Saraswati, P.K \& Sabnis, S.V. 2006. Comparison of CART and discriminat analysis of morphometric data in foraminiferal taxonomy. Anuario do Instituto de Geociencias. Ind Fish Res J 29: 153-162.

Schaeffer, K.M. 1991. Geografic variation in morphometric characters and gill-raker counts in yellowfin tuna (Tunnus albacares) from Pacific ocean. Fish Buletin 89: 289297.

Sprent, P. 1972. The mathematics of size and shape. Beometric (28): 23-37.

Strauss, R.E \& Bookstein, F.L. 1982. The truss: Body form reconstruction in morphometrics. Syst Zool 31: 113135.

Sunarno, M.T.D., Wibowo, A \& Subagja. 2007. Identifikasi tiga kelompok ikan belida (Chitala lopis) di sungai Tulang Bawang, Kampar dan Kapuas dengan pendekatan biometric. Jurnal Perikanan Indonesia 13(2): 87-94.

Syandri, H., Basri, Y., Aryani, N \& Azrita. 2008. Kanjian kandungan nutrisi telur ikan bilih (Mystacoleucus padangensis $\mathrm{Blkr}$ ) dari limbah hasil penangkapan nelayan di Danau Singkarak. Jurnal Perikanan dan Kelautan 13(1): 118-126.

Syandri, H., Azrita \& Aryani, N. 2009. Peningkatan daya reproduksi ikan Kiung (Channa lucius Cuvier) dengan rangsangan hormon LHRH-a dan vitamin E. Jurnal Sigmatek 9(3): 19-16.

Syandri, H. 2011. Kadar nutrisi limbah telur ikan bilih (Mystacoleucus padangensis Blkr) sebagai sumber ransum pakan. Jurnal Akuakultur Indonesia 10(1): 74 80.

Turan, C., Denis, E., Turan, F \& Erguden, M. 2004. Genetic and morfometric structure of Liza abu (Heckel 1843). Population from the rivers Orontes. Eupharates and Tigris. Turk. J Vet Anim Sci (28): 729-734.

Turan, C., Oral, M., Õztürk, B \& Düzgünes, E. 2006. Morphometric and meristic variation between stocks of Bluefish (Pomatomus saltatrix) in the Black, Marmara, Aegean and northeastern Mediterranean Seas. Fish. Res 79: $139-147$.

Tzeng, T.D. 2004. Morphological variation between populations of spotted mackerel (Scomber australasicus) off Taiwan. Fish Res 68(1-3): 45-55.

Wibowo, A., Sunarno, M.T.D., Makmur, S \& Subagja. 2008. Identifikasi struktur stok ikan belida (Chitala spp) dan implikasinya untuk manajemen populasi alami. Jurnal Penelitian Perikanan Indonesia 14(1): 31-44.

Wibowo, A., Sunarno, M.T.D., Subagja \& Hidayah, T. 2009. Karakterisasi populasi ikan putak (Notopterus notopterus) menggunakan analisis keragaman fenotipik dan daerah 16SRNA DNA mitokondria. Jurnal Penelitian Perikanan Indonesia 15 (1): 1-12. 